\title{
Política indigenista amazônica e os meandros da justiça nas cartas de Pe. Antônio Vieira
}

\author{
Amazonian indigenist policy and between the lines of justice in the letters of Priest \\ Antonio Vieira \\ Ludmila Gomides Freitas \\ https://orcid.org/0000-0001-5964-2487 \\ Universidade Federal de São João del-Rei
}

Resumo: A partir dos discursos políticos de Pe. Antônio Vieira, pretendemos analisar a aplicação da justiça no arbítrio sobre as guerras justas contra os índios na Amazônia portuguesa seiscentista. As fontes analisadas no artigo - cartas e pareceres de Vieira revelam a transposição do dispositivo legal à realidade social da colônia, evidenciando os conflitos jurisdicionais e o caráter casuísta da justiça. Serão discutidos os conteúdos teológico-jurídicos sobre os quais as disposições e o discurso vieiriano se assentavam, notadamente, no pensamento de Luís de Molina, importante jesuíta português da Segunda Escolástica. Mostraremos, enfim, os modos como se dava a circulação e recepção das ideias políticas e teológicas no vasto Império português durante a Época Moderna.

Palavras-chave: Pe. Antônio Vieira; guerra justa; pensamento jurídico-teológico

\begin{abstract}
We intend to analyze the application of justice in arbitration on the fair battle against the Indians in the Portuguese Amazon seventeenth century, starting from the political discourses of Priest Antonio Vieira. The sources analyzed in the paper - letters and opinions of Vieira - reveal the reveal the transposition of the legal provision to the social reality of the community, evidencing the jurisdictional conflicts and the casuistic character of justice. The legal-theological contents on which the dispositions and the discourse of Vieira were based, notably, on the thought of Luis de Molina, an important Portuguese Jesuit of the Second Scholasticism, will be discussed. We will show, finally, the ways in which the circulation and reception of political and theological ideas in the wide Portuguese Empire during the Modern Age was given.
\end{abstract}

Keywords: Priest Antonio Vieira; fair battle; legal-theological thinking

As missões jesuíticas desempenharam papel fundamental na consolidação do domínio colonial na região amazônica, sendo, pois, responsáveis pela propagação da Fé e pela manutenção dos mecanismos de controle e subordinação dos índios. A inclusão do indígena no corpo místico e político da monarquia cristã portuguesa e sua utilização como mão-de-obra eram projetos políticos que, embora não excludentes, estiveram em disputa permanentemente, marcando a relação conflituosa entre jesuítas, autoridades coloniais e moradores. $\mathrm{Na}$ região amazônica, especialmente, a dependência do "serviço dos índios" foi um problema sensível durante todo o período colonial. Nesse sentido, a ação evangelizadora da Companhia de Jesus esteve, a todo tempo, permeada pela questão do trabalho indígena e pelos conflitos com os colonos 
daí decorrentes ${ }^{1}$.

De um modo geral, a historiografia tem enfatizado a importância de Pe. Antônio Vieira para consolidação, organização e desenvolvimento das missões amazônicas fato que ele próprio reforça em inúmeras cartas. Nesse sentido, é comum à fortuna crítica de Vieira referir-se ao período de sua missionação no Maranhão e Grão-Pará (1653-1661) como um dos mais combativos em defesa do projeto evangelizador e civilizatório do indígena. Boa parte da produção discursiva deste período, seja ela parenética ou epistolar, versou sobre o propósito de defender os índios da guerra desenfreada, dos cativeiros injustos e da violência de toda sorte. Suas cartas, pareceres e informações tiveram um considerável alcance político, pois ao serem remetidos ao rei e a seus conselheiros, forneceram, por vezes, as informações que subsidiaram a escritura das leis indigenistas. Isto é válido, sobretudo, durante o reinado de D. João IV, quando Vieira contou com especial apreço da Coroa portuguesa².

As informações e as cartas de Vieira do período amazônico deixam explícita a conturbada relação do missionário com os colonos e as autoridades locais. O motivo da desavença parece ter sido precisamente o critério pelo qual os moradores ou "portugueses" (como Vieira os chama genericamente) escravizavam os indígenas a pretexto de que tinham sido apresados em guerras justas. Este era, fundamentalmente, um dos critérios legitimadores da escravidão, e que, no alvorecer da modernidade, foi amplamente debatido em suas bases jurídico-teológicas pela Segunda Escolástica.

O direito de guerra mobilizado na situação de embate contra os índios reportavase a uma longa tradição jurídica, onde a distinção entre fiéis e infiéis consistia no elemento definidor da ética-moral da guerra justa. Se antes dos encontros com o Novo Mundo a escravização por guerra justa era justificada pela dominação dos infiéis, que conscientemente recusavam-se à conversão, no contexto americano, o cativeiro de índios pagãos suscitou novas elaborações jurídicas e teológicas. Sumariamente, a escravidão passou a fundamentar-se na distinção entre índios mansos e índios bravios. Era precisamente "[...] no rompimento dessa situação de amizade e paz que residia a necessidade prática e a justificativa moral para a escravidão" (Domingues, 2000, p. 27).

As cartas e pareceres de $\mathrm{Pe}$. Vieira nos dão pistas para que possamos compreender a política e a legislação indigenistas voltadas à região amazônica, tal como a disputa entre colonos e jesuítas pelo monopólio da mão-de-obra dos índios. Ao se reportarem a situações de conflito específicas da sociedade colonial - situações de conflito aberto entre padres e colonos, guerra contra os índios, descimentos, resgates etc. - conseguimos por meios dessas fontes mapear o contexto e os usos das tópicas do direito de guerra, de escravidão e liberdade indígenas então mobilizadas. Neste artigo, temos o objetivo de demonstrar como o conceito de guerra justa - tal qual elaborado no âmbito da Segunda Escolástica, particularmente nas ideias de Luís de

\footnotetext{
${ }^{1}$ As relações tecidas entre os inacianos e os moradores do Estado do Maranhão e Grão-Pará revelaramse bastante complexas, e seu entendimento demanda um olhar que vá além do antagonismo. Rafael Chambouleyron, Karl Arenz e Raimundo Neves Neto, por exemplo, chamam atenção para o fato de que os jesuítas cumpriram importante papel em instâncias fundamentais da sociedade colonial amazônica, como a pastoral e a educação dos filhos dos colonos. Portanto, tais relações não se limitaram às disputas pela mão-de-obra indígena, ainda que esse fosse o ponto nodal. Ver: CHAMBOULEYRON; ARENZ; NEVES NETO, 2011.

2 Durante o reinado de D. João IV (1640-1656) Vieira foi seu confessor, dileto conselheiro político e embaixador nas mais importantes cortes da Europa, antes de ser designado superior das missões no Brasil, em 1653. Foi durante seu período como missionário, que Vieira participou ativamente na determinação das políticas indigenistas. Como exemplo, podemos citar a Lei de Liberdade de 1655, dispositivo que afirmava a liberdade dos índios e o poder temporal da Companhia de Jesus sobre os aldeamentos.
} 
Molina - subsidiavam o discurso vieiriano, a política indigenista e a aplicação da justiça na porção amazônica da América portuguesa seiscentista. Ademais, teremos aqui a possibilidade de atestar o caráter casuísta do discurso do jesuíta, apto a responder a questões divergentes evocando a experiência histórica.

É importante notar que, mesmo a legislação não sendo cumprida - haja vista as guerras injustas e a escravização ilícita de milhares de índios - ela exercia, ainda assim, um efeito coercitivo sobre os colonos, ainda que no plano simbólico. Havia, pois, entre eles a expectativa de serem contemplados com leis que visassem o bem comum. $O$ que, no caso, significava a possibilidade de explorar a mão-de-obra indígena sem limites e sem a interferência dos padres jesuítas. Portanto, é preciso ter claro que, o fato de a lei não ser obedecida não significava indiferença em relação a ela, caso contrário, não entendemos as razões dos protestos e motins que se seguiam ao anúncio das leis mais favoráveis ao projeto missionário dos jesuítas. Concordamos com John Hemming quando diz que, "tais reações mostram que as leis eram encaradas seriamente, ainda que fossem escarnecidas com frequência" (Hemming, 2007, p. 455).

A noção de bem comum implicava, até certo ponto, o conjunto dos interesses particulares reunidos, uma vez que a teoria social e jurídica dos séculos XVI e XVII, "[...] embora distinguia o interesse dos particulares do interesse geral, considera-os como componentes harmônicos duma unidade mais vasta: o bem comum" (Hespanha, 1984, p. 29). Porém, do modo como era concebida pelos colonos, a noção estava deturpada, pois eminentemente voltada à satisfação de seus interesses econômicos imediatos. $\mathrm{Na}$ interpretação de Vieira - afinada ao pensamento da Segunda Escolástica - o bem comum somente poderia ser capitaneado pela figura do rei, que, como cabeça do corpo político, era o único capaz de assegurar seu contorno essencialmente político e teológico. Enfim, o único capaz de dirimir os impulsos centrífugos dos interesses particulares ${ }^{3}$. Por conseguinte, a ideia de bem comum carregava fundamentalmente um cariz conciliatório.

O mais importante a ser destacado é que, na colônia, a acepção de bem comum esteve todo tempo em disputa4: os jesuítas, por exemplo, defendiam que o único meio de garantir o sentido evangelizador da colonização portuguesa, era manter os índios sob o controle temporal dos padres nos aldeamentos, servindo aos colonos segundo os critérios da lei, ou seja, durante um determinado período e mediante a remuneração dos trabalhos. Por sua vez, os moradores (representados pelas Câmaras Municipais) recorrentemente acusavam os jesuítas de monopolizarem a mão-de-obra indígena visando, não ao bem comum, mas à satisfação de seus próprios empreendimentos econômicos.

Durante os séculos XVI e XVII, a concentração de poder e a jurisdição temporal sobre os índios nas mãos da Companhia foram razões de conflitos e disputas com os colonos. Tais fatos colocavam ao poder metropolitano a difícil tarefa de equilibrar os interesses divergentes, porém, igualmente importantes para a viabilidade da colônia. Daí advém a propalada ambiguidade da legislação indigenista que, no entanto, deve ser percebida como uma estratégia de acomodação política posta em prática pelo poder

\footnotetext{
3 Isso não significa postular a existência de um poder absoluto dos reis. Os estudos portugueses e brasileiros mais recentes sobre a estrutura institucional e de poder no interior do Império reavaliaram a centralidade do poder monárquico. De uma maneira geral, a historiografia vem revisitando e contestando alguns paradigmas clássicos acerca da centralidade do Estado Absolutista e sua consequência direta, a precoce atrofia dos poderes locais. Esses estudos têm procurado reforçar a ideia da relativa autonomia dos poderes municipais face aos dispositivos institucionais de controle por parte da Coroa.

${ }_{4}^{4}$ Para o entendimento da categoria de bem comum na América portuguesa, ver: ZERON, 2009.
} 
real.

Uma visada superficial do extenso corpus documental da legislação indigenista indica o movimento oscilante entre leis que defendiam a liberdade irrestrita dos naturais da terra e leis que permitiam a escravidão em determinados casos (mormente, as guerras justas e os resgates de índios de corda) ${ }^{5}$. No entanto, esta ambiguidade deve ser percebida como uma estratégia do poder metropolitano para acomodar os conflitos e os interesses de setores basilares daquela nascente sociedade. Num jogo político e jurídico essencialmente casuísta e pragmático, as leis de liberdade e escravidão respondiam às urgências colocadas a cada circunstância histórica: por vezes, sustentando o caráter cristão da colonização e, consequentemente, apoiando a Companhia de Jesus; em outros muitos momentos, cedendo aos imperativos econômicos dos colonos. O equilíbrio e a concórdia do corpo social eram, pois, a finalidade da administração e da justiça que, contudo, foram incapazes de mediar projetos que se mostravam inconciliáveis na prática. Enfim, o que predominou foi a tensão entre jesuítas e colonos, além de episódios mais graves como a expulsão dos missionários, entre eles, padre Vieira, em 1661.

Nesse artigo, iremos acompanhar os meandros da aplicação da justiça a partir de dois episódios em que os colonos (representados pelas autoridades locais e prelados de ordens mais condescendentes com a escravidão dos nativos) enfrentaram o poder da Companhia de Jesus, protagonizado por Pe. Antônio Vieira. Pela análise de dois escritos do jesuíta ${ }^{6}$, identificaremos a maneira pela qual as teorias teológico-jurídicas aparelhavam os debates realizados em Câmara. Embora nossa análise esteja restrita ao testemunho de Vieira, ainda sim, é possível identificar que seus opositores também construíam seus argumentos referenciados pelas tópicas teológico-jurídicas, explicitando, pois, como se dava a circulação de ideias políticas no Império português no alvorecer da Época Moderna. Eminentemente casuístas, as tópicas da guerra-justa eram suficientemente plásticas para reiterar posições antagônicas. Vieira tentará, por meio de sua erudição e engenho, fixar sua opinião como a mais prudente e ortodoxa. $\mathrm{O}$ devir dos acontecimentos mostraria, contudo, o revés do projeto político-missionário jesuítico.

\section{Um jesuíta no sertão amazônico}

Pe. Vieira, investido do cargo de superior das missões, desembarcou pela

\footnotetext{
${ }^{5}$ As pesquisas de Beatriz Perrone-Moisés foram fundamentais para matizar as interpretações que definem a política indigenista como oscilante e contraditória. Segundo a autora, "[...] fala-se de "liberdade dos índios" e "escravização dos índios" como se, em ambos os casos, as leis se referissem a todos os indígenas do Brasil, indistintamente". Todavia, evita-se a armadilha de qualificar a política indigenista portuguesa como contraditória e volúvel mediante a distinção dos grupos de índios a que se referiam as leis de liberdade e escravidão. Sem essa separação corre-se o risco de confundir o aspecto puramente jurídico com a realidade histórica da escravidão. As nações indígenas que se relacionaram com os portugueses eram diferenciadas juridicamente em índios aliados e aldeados e índios inimigos e hostis dispersos pelo sertão. Aos índios aliados e aldeados, a soberania sempre foi afirmada: eram livres e senhores de suas terras nos aldeamentos, passíveis de serem requisitados para trabalhar para os colonos em troca de salário e bom tratamento. Eram, dessa forma, as garantias do desenvolvimento da colônia e de sua defesa. Já os índios inimigos, capturados nas guerras justas, podiam ser escravizados pelos moradores. (Perrone-Moisés, 1992, p. 117).

${ }^{6}$ Nesse artigo, iremos analisar detidamente os seguintes documentos: VIEIRA, Pe. Antônio. "Informação sobre o modo com que foram tomados e sentenciados por cativos os índios do ano de 1655" e "Direcções a respeito da forma que se deve ter no julgamento e liberdade no cativeiro dos índios do Maranhão" (Pará, 29 de setembro de 1655). In: Pe. Antônio Vieira. Obras Escolhidas. Prefácio e notas de Antônio Sérgio e Hernani Cidade. Vol.V - Obras Várias, 1951.
} 
primeira vez no Estado do Maranhão em janeiro de 1653. A vinda do jesuíta tinha por objetivo revitalizar as missões amazônicas, uma vez que seus confrades haviam malogrado em estabelecer relações amistosas com os índios da região, vide o martírio do Pe. Luis Figueira em 1640, chefe da missão, pelas flechas dos índios na Ilha de Marajó. De acordo com Camila Loureiro Dias, Vieira tinha como objetivo

[...] reger as relações entre índios e moradores, implantar e fazer operar uma Missão jesuíta que estruturasse e regulamentasse a fixação colonial portuguesa e a exploração do trabalho indígena na região. Sua ideia era fazer amizade com os índios de dois territórios estratégicos, justamente áreas de influência holandesa: a serra de lbiapaba, onde havia índios tobajaras e muitos tapuias, e a ilha de Joanes (Marajó), onde Vieira estimava habitar mais de 40 mil nheengaíbas. Já os índios da região interior, para além da foz do Amazonas em direção a oeste, seriam aqueles de quem se obteriam trabalhadores (Dias, 2017, p, 242).

Pe. Vieira contava com o apoio do novo governador, André Vidal de Negreiros, que trazia do reino uma lei partidária à liberdade dos índios e ao projeto da Companhia de Jesus. A situação na colônia era, porém, bastante complicada. O fracasso das missões no interior da floresta era fruto da dificuldade de conversão de "gentes bárbaras", mas, sobretudo, dos "costumes pouco cristãos" dos colonos que escravizavam ilegalmente os naturais da terra.

Diante dessa situação, Vieira resolve voltar a Portugal para pedir a D. João IV leis mais duras que coibissem a situação de violência e cativeiros indiscriminados. $\mathrm{Na}$ corte, Vieira é bem-sucedido em seu intento ${ }^{7}$. A nova provisão real de 09 de abril de 1655 atribuía plenos poderes à Companhia nos assuntos temporais e espirituais dos aldeamentos. Caberia aos jesuítas autorizar as expedições de resgate e opinar quando se tratava de decidir quais eram os índios legalmente cativos. Conforme a "Informação" de Vieira, a lei mantinha o direito de escravização nos seguintes termos:

Primeiro, em guerra defensiva ou ofensiva que nós dermos aos ditos Índios. Segundo, se eles impedirem a pregação do Sagrado Evangelho. Terceiro, se estiverem presos à corda para serem comidos. Quarto, se forem tomados em guerra justa, que uns tiverem com os outros. E quando constasse que foram tomados em guerra injusta os ditos índios, ainda no tal caso concede Sua Majestade que se possam resgatar e comprar aos Gentios que os tiverem por escravos, não para ficarem cativos, mas para servirem cinco anos em satisfação do preço que se tiver dado por eles. (Vieira, 1951, p. 38).

É, pois, sobre o quarto critério que iremos nos deter. Dada a prerrogativa dos jesuítas em asseverar a legalidade ou ilegalidade dos resgates, Vieira detalhou em seus discursos o conflito gerado em torno da aplicação da lei. Enfim, as fontes exemplificam a tentativa de transpor os casos previstos no dispositivo legal à realidade social da colônia, além de debater sob quais conteúdos teológico-jurídicos as disposições se assentavam.

A primeira consideração referia-se aos casos de cativeiro quando os índios "estiverem presos à corda para serem comidos". Aqui não havia dúvidas: "Constando ser assim, sem mais exame de justiça de seu cativeiro se deve julgar em consciência que podem ser resgatados como verdadeiros escravos [...]" (Vieira, 1951, p. 28). O problema surgia no exame dos casos em que os índios, embora presos por nações

\footnotetext{
${ }^{7}$ Em Lisboa, uma junta de letrados foi chamada para arbitrar sobre a questão indígena. Nela participaram clérigos das ordens que missionavam no Maranhão e Grão-Pará, teólogos, desembargadores do Paço, deputados da Mesa de Consciência e Ordens, além, é claro, de Antônio Vieira.
} 
inimigas, não corriam o risco de morrer em ritual antropofágico. Nestes casos, a questão era averiguar sob qual título foram tomados por cativos e, em caso de terem sido aprisionados por guerra, o problema seria determinar sua justiça ou injustiça. Vieira passa, então, a considerar cada um dos casos:

Se for por via de origem, e disserem que são escravos, por serem filhos de outros escravos, se não houver memória da causa de seu cativeiro, se devem julgar por legitimamente cativos, por razão da boa-fé dos últimos possuidores. Porém, havendo notícia da causa por que os pais dos tais escravos incorreram o cativeiro (a qual entre estes não costuma ser outra, senão a guerra, por não terem outras leis a que esteja imposta esta pena) no tal caso se averiguará a justiça da dita guerra, e se fará dela o juízo que das demais. (Vieira, 1951, p. 29).

Nota-se que o comentário sobre a lei se reporta aos títulos legítimos de escravização, que tem sua origem no direito romano e na jurisprudência medieval. A origem, ou nascimento - partus sequitur ventrem - é um título que raramente foi questionado. Portanto, se os escravos são "filhos de outros escravos", é lícito o cativeiro e deve-se dar "razão a boa-fé dos últimos possuidores".

Quando se averiguava que os cativos haviam sido presos durante as guerras intertribais, a dificuldade estava em determinar a justiça ou injustiça da guerra. Portanto, temos aqui a tentativa de transpor a ética de guerra da tradição cristã ocidental para o universo cultural indígena. Tal postura é reflexo de uma prática bastante recorrente quando se observa o encontro de culturas profundamente dissemelhantes. A forma mais primária de decodificação do outro (indígena) realizada pelo europeu foi, sem dúvida, o reconhecimento por meio de analogias ${ }^{8}$. O olhar europeu, referenciado por sua própria cultura, não poderia dispor de instrumentos cognitivos e semânticos capazes de apreender a singularidade da cultura indígena, pois, nos séculos XVI e XVII, era impensável uma compreensão fora do universo cristão. Em suma, ser-lhes-ia impossível um olhar relativista. Assim, a guerra intertribal haveria de ser apreendida pelos quadros mentais do homem europeu dos séculos XVI e XVII, ou seja, pela lógica e pelos critérios da guerra justa.

Algumas considerações fazem-se necessárias antes de prosseguirmos à análise dos discursos de Pe Vieira.

\section{Os jesuítas no Novo Mundo: o encontro possível com a alteridade}

A chegada do europeu à América marcou, em conjunto com o Renascimento, a descoberta do "outro" e, na esteira desse processo histórico-cultural, ocorreu, paralelamente, a "construção da Igualdade" (Agnolin, 2007, p. 478). Essa ideia, proposta por Adone Agnolin, sustenta-se no argumento de que houve, no século XVI, um duplo reconhecimento: o de uma alteridade histórica e interna à Europa e de uma outra contemporânea e externa. Segundo o autor:

Com efeito, através do encontro emblemático entre uma alteridade histórica (os antigos) e uma alteridade espacial (os selvagens), o século XVI representou o momento mais significativo do percurso que constituiu os homens na base de uma mesma estrutura subjetiva e das mesmas representações. Nessa perspectiva, a cultura ocidental encaminhou-se em direção à construção de uma Igualdade, que permitiu a possibilidade inédita de comparação horizontal [...], com os consequentes efeitos de historicização das alteridades históricas e espaciais.

\footnotetext{
8 Ver: PAGDEN, 1982.
} 
(Agnolin, 2007, p. 23)

No bojo desse processo, construiu-se o entendimento de que os indígenas do Brasil eram "próximos" - assim concluiu o jesuíta Manuel da Nóbrega - muito embora fossem como "cães em se comerem e matarem" (Nóbrega, 1954). No interior da escala de comparação horizontal das diferentes culturas, os brasis figuravam na posição mais inferior. Segundo Carlos Zeron, esta tese foi exposta por diversos cronistas, entre eles o jesuíta José de Acosta, que criou uma taxonomia dos povos contatados a partir da expansão europeia. Segundo Zeron, "[...] a última categoria descrita pelos cronistas, a mais afastada do referente político e social cristão ocidental, aproxima os índios mais das feras dos que dos seres humanos. Categoria extrema esta localizada no Brasil, e eventualmente no caribe" (Zeron, 2011, p. 384). Portanto, somente o ingresso na civilidade por meio da conversão e do trabalho, garantiria aos índios a possibilidade de diminuir a sua imensa distância do plano divino 9 .

Para os jesuítas, a conversão pela via pacífica era o expediente ideal para a incorporação do gentio ao corpo místico e político da monarquia cristão portuguesa. Contudo, as guerras e a decorrente escravização, quando rigorosamente limitadas pelos critérios da lei - lei esta em conformidade com a razão teológica - raramente foram questionadas como forma de fazer do gentio um fiel e vassalo produtivo da empresa colonizadora. Aqui, entende-se que a conversão não é forçada (uma vez que a verdadeira aceitação da Palavra tem como condição primeira a escolha livre), contudo, a submissão ao poder temporal, ao disciplinar o corpo e extirpar os maus costumes contribuiria efetivamente para que, num segundo momento, se desse a conversão.

\section{A guerra justa cristã e a guerra selvagem}

Como dito anteriormente, no documento "Informação sobre o modo com que foram tomados e sentenciados por cativos os índios do ano de 1655", Vieira busca transpor a ética de guerra da tradição cristã ocidental para o universo cultural indígena. Para ele, a licitude da escravização dos índios dependeria da confirmação de que as guerras travadas entre eles fossem passíveis de serem enquadradas nos critérios da guerra justa.

O jesuíta entendia que se a guerra intertribal, julgada pelos parâmetros da ética de guerra cristã, fosse considerada justa, nada mais adequado do que resgatar o índio do cativeiro entre seus iguais (selvagens) e transformá-lo em escravo cristão e vassalo do reino português. Constatando-se que a guerra indígena fora injusta, ainda assim, o indígena seria obrigado a servir ao português durante cinco anos e, consequentemente, teria aí a oportunidade de abandonar a gentilidade e tornar-se cristão. Nas palavras de Vieira:

Se os cativos feitos em guerra, se averiguará se foi justa ou injusta; e achando-se ser injusta, poderão ser resgatados conforme a lei de Sua Majestade, para servirem cinco anos, que é o que vulgarmente chamam de escravos de condição. Constando ser a guerra justa, não há dúvida serem tomados nela legitimamente escravos [...]

\footnotetext{
${ }^{9}$ Cabem aqui as explicações de Agnolin: "Em primeiro lugar, [...] a "conversão" se delineia no seu novo e fundamental aspecto de não mais voltar para uma origem (inscrita no passado) de perfeição que teria sido perdida, mas em direção a uma 'evolução' (inscrita no futuro) que pretende inscrever as novas populações num 'processo civilizador' que se imporia juntamente com o processo de cristianização: trata-se de uma inscrição numa 'dimensão religiosa' ligada à peculiaridade de uma religião (ocidental), caracterizada por uma fides que se configura, ao mesmo tempo, como uma fidelitas ao ordenamento político (do príncipe)." (Agnolin, 2007, p. 72)
} 
(Vieira, 1951, p. 30).

O caso identificado como "escravo de condição" é bastante curioso. Identificamos aqui um título de escravidão legítimo, derivado do direito de guerra, que é inédito, pois forjado para atender o contexto da expansão colonial na América portuguesa. Nesse sentido, estas considerações vão ao encontro das ideias de Dias quando afirma que

Ao olharmos para o Estado do Maranhão, observamos que, em torno de princípios jurídicos que se mantiveram durante todo o período colonial (sobre os casos em que seria legítima a redução dos índios à escravidão), fatores históricos, econômicos e políticos levaram a uma progressiva adaptação e flexibilização do regime de obtenção de escravos, e de outras formas de trabalho forçado indígena, a partir do final do século XVII e durante a primeira metade do século XVIII (Dias, 2017, 241)

O índio feito cativo por uma tribo inimiga, ainda que fosse aprisionado em guerra injusta, não era posto em liberdade, mas obrigado a servir aos portugueses por tempo determinado. Como vimos, essa era uma oportunidade para o índio ser catequizado e, além disso, era justo que os colonos envolvidos na operação de resgate fossem ressarcidos de seus custos. Nota-se que aqui está subjacente a concepção agostiniana sobre o homem: o cativeiro do corpo não impõe ou significa, o cativeiro da alma.

Os critérios determinantes de guerra justa ou injusta eram os mesmos adotados para as guerras de cristãos contra infiéis:

Primeira: Se a guerra for meramente defensiva, verbi gratia, se os Aroans [Arauaks] foram fazer guerra aos Nheengaíbas, sem eles Ihes darem legítima ocasião para isso, todos os Aroans que forem tomados pelos Nheengaíbas serão seus legítimos e verdadeiros escravos. Segunda: Se a guerra for ofensiva, só será legítima e justa, quando for feita por autoridades ou consentimento de toda a nação ou de toda a aldeia e quando tiver legítima causa, isto é, quando for feita ad resarciendam injuriam, a qual injúria também, para ser legítima, há de ser grave e feita não por uma ou algumas pessoas particulares, propria autoritate, senão pelo principal da nação ou aldeia, ou pelos outros do seu consentimento (Vieira, 1951, p. 30)

Há uma clara tentativa de Vieira adaptar as cláusulas da ética bélica cristã ao universo social e político das tribos: na guerra ofensiva entre os indígenas, a injúria deveria ser perpetrada pelo "principal" (cacique) ou "pelos outros do seu consentimento", visto não haver entre eles a figura do rei. Vemos aqui, mais uma vez, o casuísmo jesuítico em operação: a doutrina fora adaptada para responder aos casos concretos colocados pela experiência histórica, sem, contudo, deixar de ser ortodoxa.

Continuemos com Vieira:

No caso que, feitas as diligências, não constar claramente da justiça da guerra, in dubio se deve presumir que foi a guerra injusta; porque assim costumam as mais vezes ser as dos Bárbaros [sic], e assim o julgam comumente os doutores, falando de nações muito mais racionais e políticas que as deste Estado, como são as da costa da África. (Vieira, 1951, p. 30)

Nesta passagem, as afirmações de Vieira remetem-se às doutrinas desenvolvidas pelos teólogos portugueses da Segunda Escolástica, a Luís de Molina (1535-1600) em especial. O jesuíta, lente prima de teologia da Universidade de Évora, foi autor de um tratado que discute os problemas de consciência advindos do tráfico de escravos africanos. Em sua obra Justitia et Jure (1594), Molina analisa as dúvidas 
atinentes às modalidades de apresamento dos escravos e propõe os critérios para os cativeiros lícitos, os meios de averiguá-los e as condições que legitimariam o trato mercantil de africanos para a América. Interessa-nos aqui apresentar brevemente essas ideias, pois, assim, vislumbramos a base teológica pela qual Antônio Vieira se fiava. Ademais, temos a oportunidade de analisar como os discursos políticos e jurídicoteológicos circulavam pelas diferentes partes que compunham o vasto Império português na Época Moderna.

\section{A Segunda Escolástica, Luis de Molina e os debates sobre a guerra justa e escravidão}

O jesuíta português Luís de Molina, na obra Justitia et Jure (1594), desenvolveu sua doutrina sobre a legitimidade do tráfico transatlântico de escravos a partir das fontes de Aristóteles, da Patrística, de São Tomás de Aquino e dos doutos da Segunda Escolástica (Francisco de Vitória e Domingo de Soto), muito embora tenha dado bastante destaque às coletâneas do direito civil e canônico. Em seu tratado, os títulos legítimos de escravidão dos africanos eram os mesmos definidos pela tradição: guerra justa, origem, a venda de si mesmo ${ }^{10}$ e comutação da pena de morte. Entretanto, a apresentação de um título de compra per si, não garantia ao traficante que os escravos não tivessem sido "mal havidos". Em razão disso, era necessário proceder a um inquérito para averiguar as condições do apresamento. Interessa-nos, particularmente, a discussão de Molina sobre a guerra justa.

Em primeiro lugar, destacamos que o jesuíta tece seus comentários fundamentado na tradição jurídica e teológica, mas, também, caucionado pelas informações dadas por pessoas diretamente envolvidas (jesuítas em missão na África e mercadores de escravos). Isso demonstrava, pois, a valorização da experiência prática e a importância de se considerar, particularmente, caso a caso. O inquérito foi, portanto, um dos instrumentos propostos por Molina para que se confirmasse a justiça dos títulos de escravização.

Diante das descrições da organização política e da condição cultural dos povos africanos, os inquéritos revelavam que não existiam títulos legítimos de redução ao cativeiro dos negros africanos: suas guerras não se conformavam a nenhuma ideia de justiça e suas organizações políticas eram precárias. Ademais, a presença dos mercadores de escravos portugueses na costa africana fazia com que as guerras intestinas se intensificassem, aumentando sobremaneira os cativeiros injustos. Nas palavras de Molina,

Entre eles, raros são os reis poderosos que tenham submetido várias nações. $O$ poder é, antes, dividido entre numerosos régulos, pequenos chefes e outros senhores semelhantes. Desde longa data, e muito antes dos nossos ali chegarem, numerosas guerras intestinas grassavam entre eles, com as nações lutando entre si e fazendo mal umas às outras por todos os meios e, com toda a evidência, sem uma sombra de direito e de justiça. Assim, as nações que se submeteram ao poder destes régulos reduzem com frequência à escravidão um bom número de súditos dos outros príncipes e os vendem em seguida aos portugueses (Molina apud Zeron,

\footnotetext{
10 O conceito de escravidão voluntária gerou intenso debate teológico no século XVI, sobretudo na disputa entre os jesuítas Manuel da Nóbrega e Quirício Caxa, que discutiram sua aplicação entre os índios do Brasil. Esse título (que tem origem no Código Justiniano) dava direito a um indivíduo vender a si mesmo ou a um pai vender seu filho, mediante uma situação de "grande necessidade". A polêmica girou em torno do conceito do que se entendia por "grande necessidade" ou "extrema necessidade". (Eisenberg, 2000).
} 
2011, p. 281).

Para Molina, enfim, os cativos eram oriundos, no mais das vezes, de guerras injustas, porém elas oportunizavam ao africano, gentil ou infiel, tornar-se cristão. Definitivamente, a conversão não conferia nenhum título legítimo de escravidão, entretanto, como bem observa Zeron em sua análise dos argumentos de Molina, "[...] a sorte dos escravos [de acordo com o jesuíta] é melhor na América ou na Europa do que na África, onde têm de submeter-se ao islamismo" (Zeron, 2011, p. 283).

Feitas estas considerações, à luz da doutrina e da experiência histórica, Molina constata um impasse intransponível entre a "coerência teórica dos títulos legítimos de redução de outrem à escravidão" e as chances irreais de se proceder aos inquéritos e às averiguações, mormente pela falta de interesse e pela má consciência dos traficantes (Molina apud Zeron, 2011, p. 293). Para o jesuíta,

E isso basta para condenar como um pecado mortal a injustiça do comércio de escravos de que se trata aqui. Porque os portugueses não se preocupam de modo algum com a justiça das guerras africanas, nem com os demais títulos em virtude dos quais se reduzem à escravidão as pessoas que se compram. Antes, compram indistintamente todos os que Ihes são oferecidos. (Molina apud Zeron, 2011, p. 293)

A impossibilidade de realização dos inquéritos é constatada, porém esse instrumento de averiguação continuou a fazer parte da legislação. Nesse sentido, a afirmação da necessidade do inquérito serviu para amainar a má consciência dos títulos injustos. Convencionou-se que, na prática, o que havia era uma dúvida insolúvel sobre as condições do apresamento. Assim, a enunciação de uma ignorância invencível permitiu que o tráfico fosse justificado, jurídico e teologicamente; isto porque, no caso de dúvida sobre a origem e o título do escravo, prevalecia o direito de propriedade, em detrimento do direito de liberdade do cativo.

Enfim, teólogos como Molina tiveram uma função determinante na legitimação do tráfico de escravos - desde que fossem preservados certos quesitos e que se garantisse o bom tratamento dos cativos - num momento em que Portugal tornara-se detentor do monopólio do tráfico negreiro para a América. A contribuição dos teólogos jesuítas foi, portanto, essencial para a edificação do Império português.

\section{A circulação das ideias jurídico-teológicas: Vieira e Molina}

Consideramos que muitos argumentos e reflexões de Luis de Molina encontram ecos nos discursos de Pe. Antônio Vieira. Se em meados do século XVII não havia mais a urgência de se legitimar a conquista e a submissão dos povos nativos, esse, todavia, continuava um tema espinhoso para política portuguesa, explícito na conturbada relação entre jesuítas, moradores e autoridades na região amazônica. Vieira foi, de fato, um protagonista desses embates, tanto na colônia como na corte. Porém, interessa-nos aqui perceber a identificação que Vieira mantinha com seus confrades teólogos: Molina, particularmente, discute a questão da justiça dos títulos de escravidão dos africanos, mas seu tratado é abundante em comentários sobre a justiça da guerra e a legitimidade do cativeiro dos índios americanos.

Como vimos, Vieira, na esteira de Molina, executa o inquérito dos títulos de redução ao cativeiro dos índios, e um ponto central foi, pois, o exame da justiça das guerras intertribais. Elas foram qualificadas na sua maioria como injustas, não porque houve uma averiguação precisa, mas em razão da imagem que se tinha da organização 
política das sociedades ameríndias: são todas bárbaras, os índios são feitos "cães em se comerem e matarem"11 e "suas guerras são mais latrocínios que guerras" (Vieira, 1951, p. 60). Contudo, a constatação das guerras ilícitas, ao invés de impor a restituição da liberdade dos cativos, justificava o título de "escravo de condição", pois a sorte dos índios era melhor entre os portugueses do que a permanência em seu meio original, posto que bárbaro. São notórios, portanto, os pontos que aproximam Vieira ao mestre teólogo de Évora.

Isso fica ainda mais claro na "Informação sobre o modo com que foram tomados e sentenciados por cativos os índios do ano de 1655" (Vieira, 1951, p. 60). Esse documento oferece-nos a vantagem de detalhar a tentativa de transpor os dispositivos legais aos casos concretos. Conforme a proposta dos doutos, era necessário que se considerassem as circunstâncias históricas precisas que envolviam cada caso de consciência. Àquela ocasião, estava em jogo a aplicação da nova lei trazida por Vieira e pelo governador-geral André Vidal de Negreiros, os protestos dos moradores na Câmara de Belém e a escravidão de dois mil índios resgatados nas últimas entradas no Pará.

O documento é dividido em quatro capítulos. Os dois primeiros discorrem sobre a lei indigenista em vigor (lei de 1655) e as formas como foram realizados os descimentos, enquanto os dois últimos examinam e julgam os casos. As centenas de escravos em poder dos moradores foram obtidas ao arrepio da lei: as entradas não tinham sido autorizadas e as companhias das tropas não foram acompanhadas por religiosos, e, quando o foram, estes "não se prestavam ao serviço de Deus".

Nenhuma das entradas contou com o exame dos cativeiros. Não havendo os exames in locu, as compras se fiaram na palavra dos intermediários do negócio:

Assim que toda a verdade e justiça destes cativeiros ficou na fé dos línguas ou pombeiros, os quais todos são mamalucos, mulatos, gente vilíssima e sem alma e consciência, criados nesta carniçaria de sangue e liberdades, e perpétuos instrumentos ou algozes das infinitas crueldades e tiranias, que a cobiça dos maiores tem executado naquele rio. (Vieira, 1951, p. 60)

Vieira descreve os pombeiros como intermediários que viabilizavam aos colonos a aquisição de escravos ilegítimos - fato muito semelhante ao descrito por Molina, referindo-se aos cativos africanos.

Em suma, descritos os meios e as ocasiões em que foram realizados os resgates pelos rios da Amazônia, Vieira conclui que nenhum dos casos guardou as condições impostas pela lei, portanto, todos títulos eram ilícitos, inválidos e nulos. O governadorgeral e o ouvidor seguiram o mesmo voto de Vieira, "mas os Prelados das três religiões, e o Vigário votaram que fossem absolutamente cativos" (Vieira, 1951, p. 59).

O segundo julgamento examinou os casos de índios apanhados por guerras intertribais. Na primeira parte, foram examinados os casos em que as guerras não estavam especificadas se justas ou injustas. Tal contexto demandou de Vieira uma longa exposição de argumentos. Logo de saída, o jesuíta afirmou que não havendo mais a possibilidade de se realizar, in locu, os exames das causas das guerras, consideravase que "estes índios não eram absolutamente cativos, conforme a lei de Sua Majestade". Para demonstrá-lo, Vieira expôs cinco argumentos fundamentados no pensamento jurídico-teológico, em Luís de Molina particularmente:

11 Ver: Pe. Manuel da Nóbrega. "Diálogo da Conversão do Gentio”. 
Primeiro: conforme a lei vigente somente quatro casos legitimavam os títulos de escravidão, entre eles, o caso de guerra justa. Como os índios disseram apenas que foram tomados em guerra, sem precisar as circunstâncias, "nem são nem se podem julgar por cativos tais índios" (Vieira, 1951, p. 59).

Segundo: quando a matéria é duvidosa, julga-se por presunção, "e as guerras dos Bárbaros, como são estes gentios do Maranhão", presume-se que foram injustas, visto "serem dadas por gente que não se governa nas guerras por razão nem por consciência" (Vieira, 1951, p. 60). Vieira, então, lança mão da tese molinista: "Assim o resolve Molina, tratando este ponto ex professo. A qual doutrina tem mais lugar nestes bárbaros do Maranhão, dos quais consta que suas guerras são mais latrocínios que guerras; porque os que mais podem vão cativar os menos poderosos, para os venderem aos Portugueses [...]" (Vieira, 1951, p. 60).

Terceiro: mesmo que se deseje seguir opinião contrária a de Molina e que se queira argumentar que as guerras que não seguem contratos tácitos ou explícito, também resultam em penas e danos - ainda sim, o argumento não seria válido. Pois nos casos analisados paira a dúvida e, sendo assim,

"[...] as mesmas guerras em si sempre são injustas; donde se segue claramente que esta opinião, quando o fosse, de nenhum modo se pode aplicar ao nosso caso; porque a lei de Sua Majestade, ainda que admite escravos de guerra, só os de guerra justa, qual esta não é" (Vieira, 1951, p. 61).

Quarto: na dúvida, a melhor condição era a do possuidor, "e neste caso não se duvida se os índios são de Pedro ou de Paulo; mas se duvida se os índios são livres ou cativos; e nesta dúvida está a posse da liberdade." No Pará e Maranhão, o colono não poderá gozar do privilégio de possuidor, porque a posse "não favorece senão o possuidor de boa fé", o que é contrário e notório entre esses colonos. Basta para comprová-lo, "[...] irem aos sertões contra a lei de Sua Majestade, sem cabos legitimamente eleitos, sem religiosos que examinem os cativeiros nas mesmas terras dos índios, onde se podiam averiguar, e sem se fazer inquirição alguma da justiça das ditas guerras, e que os índios fossem tomados nelas, de que também se pode duvidar" (Vieira, 1951, p. 61-62).

Quinto e último: Na dúvida deve-se preferir a parte mais segura. Se os índios forem julgados como escravos e forem, de fato, livres, seria um dano grave e irreparável mantê-los cativos por toda vida, e também a sua prole. Pelo contrário, se forem julgados erroneamente como livres, "[...] só se podia seguir perderem os compradores o preço que deram por eles; quanto mais que nem esse preço se perde, porque por ele hão de servir os ditos índios cinco anos na forma da lei; e assim votou o dito Pe. Antônio Vieira que se fizesse" (Vieira, 1951. p.62)

Os adversários de Vieira recorriam, na ausência de razões jurídicas e teológicas, aos lugares comuns do direito fundado nos usos e costumes e, diga-se, nos usos e costumes de homens cristãos: os prelados das ordens afirmavam que "[...] os índios não perdiam nada em ser cativos, e que o direito introduzira o cativeiro por piedade" " (Vieira, 1951. p. 64). A sentença, da forma como colocada, expressava, sem eufemismos, um argumento que era aceito consensualmente àquela época. Se levarmos em conta que a noção de liberdade é, ao mesmo tempo, jurídica e teológica, entendemos que, estar em liberdade, significava agir segundo a reta razão inspirada no bem que vem de Deus. Como os índios agiam movidos por outros princípios, mais perto do demônio do que de Deus, haja vista seus maus costumes, isto significava que em seu estado natural viviam 
privados da liberdade, pois ignorantes do Bem. A conversão, ainda que não conferisse legitimidade ao título de escravidão, transformava-a em algo piedoso.

Devemos ter em mente que Vieira também aceita e confirma essa concepção quando diz: "Que lhe aproveita ao homem ser senhor de todo o mundo, se tem sua alma no cativeiro do demônio?" (Vieira, s/d, p. 177). Logo, para que os índios pudessem agir livremente, deveriam ser integrados e subordinados ao grêmio da cristandade. Assim sendo, o que estava em questão eram os meios de se efetivar a submissão. Vieira, ao insistir na observância das leis, não colocava em xeque a escravidão, nem o lugar social e político que os naturais da terra deveriam ocupar. Porém, defendia que o genus angelicum do Quinto Império a ser erigido na Terra, deveria ser confiado ao poder temporal e espiritual da Companhia de Jesus. Pois, ficando como escravos nas mãos de moradores, poucas chances tinham os índios de livrarem-se da gentilidade.

O governador-geral e o ouvidor seguiram os votos de Vieira, todavia, os três prelados das outras ordens e o vigário "votaram que fossem absolutamente cativos, sem mais fundamento que por eles haverem confessado que o eram" (Vieira, 1951, p. 59). O governador-geral Vidal de Negreiros ainda tentou contemporizar com as exigências dos prelados e demais autoridades: ao invés de cinco anos, o "escravo de condição" serviria durante sete, pois segundo seu raciocínio: "Os índios que forem tomados em guerra justa, diz a lei que fiquem cativos pra sempre; os que forem tomados em guerra injusta, diz a mesma lei que sirvam cinco anos; logo, os que foram tomados em guerra duvidosa, é bem que sirvam mais algum tempo [...]" (Vieira, 1951, p. 64).

Entendemos que a tentativa do governador Vidal de Negreiros de acomodar as divergências é mais um exemplo que expressa, essencialmente, o modo como a justiça se fazia no século XVII. Como dito anteriormente, a construção argumentativa das ideias jurídicas previa zonas de acomodação das posições conflitantes. Essa maleabilidade dava-se a um nível mais superficial do problema em questão e, assim, era capaz de responder aos desafios postos pelas situações históricas de forma bastante pragmática. Portanto, no caso analisado acima, se havia a possibilidade de negociar se o índio tomado em "guerra duvidosa" serviria por cinco ou por sete anos, era porque o funcionamento da justiça permitia a construção do direito no momento mesmo em que este era exercido ${ }^{12}$.

Os prelados não voltaram atrás e Vieira foi, finalmente, voto vencido: todos os índios que disseram que estavam presos à corda foram julgados como escravos legítimos. Vieira, por fim, comenta que não foi possível realizar no Pará o exame de todos os índios resgatados, pois grande parte já havia sido vendida para os portugueses do Maranhão.

Tempo depois, na Câmara de São Luís, foram realizados novos exames e julgamentos, nos mesmos moldes até aqui descritos e com as mesmas autoridades e prelados, com exceção do ouvidor e do vigário, que foram, então, substituídos. No Maranhão,

Estes dois [o ouvidor e o vigário do Maranhão] se conformaram em quase tudo com o voto do Governador e do Pe. Antônio Vieira, que foram os mesmos, por serem os casos os mesmos [julgados na Câmara de Belém]. Os três prelados das religiões, a saber: o Provincial do Carmo, o Custódio de Santo Antônio e o Comissário das Mercês, porque se viram vencidos em votos, não quiseram assinar a sentença, a qual, e a dos Pará, com uns e outros autos vão remetidas a Sua Majestade, para

12 Sobre as particularidades do exercício da justiça e do direito na América portuguesa, ver: HESPANHA, 2006, p. 97. 
Este trecho do documento demonstra que os mesmos casos, examinados à luz dos mesmos argumentos teológico-jurídicos e circunstanciados por situações históricas muito semelhantes, resultaram em sentenças diferentes. Enquanto no Pará, Vieira fora voto vencido e não convenceu advogando a liberdade dos índios, no Maranhão, conseguira derrubar o voto dos prelados. Podemos dizer que os diferentes julgamentos expressam o caráter casuísta da justiça colonial, além de exemplificarem a flexibilidade das tópicas jurídico-teológicas enunciadas para arbitrar os casos concretos.

Em suma, procuramos demonstrar neste artigo, que o Estado do Maranhão e Grão-Pará receberam uma atenção especial do poder metropolitano no que diz respeito à política e à legislação indigenistas no século XVII. Nosso viés metodológico foi apresentar esse panorama jurídico a partir das cartas e informações de Antônio Vieira, pois, dessa forma, pudemos dimensionar o protagonismo do jesuíta nas questões que envolviam os índios. Ao mesmo tempo, pelos exemplos demonstrados, foi possível vislumbrar o modo como a justiça era concebida e administrada: vimos que as tópicas do direito de guerra eram acionadas de acordo com a particularidade das circunstâncias e, mesmo quando seus sentidos e conteúdos eram remodelados, permaneciam alinhados à ortodoxia dos fundamentos político-teológicos ${ }^{13}$. É somente no bojo de tais considerações que entendemos o sentido de se estender à guerra intertribal os critérios da guerra justa cristã. Concluímos, portanto, que a justiça era profundamente dependente da prática do direito, da realidade histórica e, igualmente, das ocasiões para o exercício da justiça.

Seguindo essa mesma lógica, compreendemos que não há paradoxo algum em Vieira defender a liberdade do índio e a exclusividade da Companhia em conduzi-lo ao corpo místico e político do Estado e, por vezes, condescender com os interesses escravagistas dos moradores. O exercício da justiça previa e impunha a adequação aos casos e este corolário era o fundamento da casuística tanto jesuítica, quanto do modelo jurídico português de Antigo Regime. Em Vieira, particularmente, a ideia de justiça remete-se naturalmente à finalidade divina e, para que o plano de Deus se cumpra, é necessário que a ação humana também cumpra, no plano da história, os desígnios providenciais. Há aqui a afirmação de que a ação política - temporal portanto - é parte essencial à via salvífica. A política das obras - fruto do livre-arbítrio, da razão e do ânimo cristão - é, enfim, condição indispensável para a salvação. Isso não implica, de modo algum, prejuízo às questões temporais da economia do Estado ou do colono, pelo contrário, a política conduzida pela moral cristã é o meio eficaz para a conciliação do bem material e espiritual.

\section{Fontes documentais}

NÓBREGA, Padre Manuel da. "Diálogo sobre a conversão do gentio". In LEITE, Serafim, Cartas dos Primeiros. Jesuítas do Brasil. São Paulo, Comissão IV Centenário, 1954, vol II.

\footnotetext{
${ }^{13}$ Ademais, o conceito de justiça não estava circunscrito à aplicação das leis positivas, uma vez que o direito comum consuetudinário e o sistema dos foros exerciam papel essencial, sobredeterminando, muitas vezes, o código escrito. Enfim, o casuísmo era a marca da administração da justiça no Antigo Regime, que era, pois, distributiva e comutativa.
} 
VIEIRA, Pe. Antônio. "Informação sobre o modo com que foram tomados e sentenciados por cativos os índios do ano de 1655". In: Pe. Antônio Vieira: Obras Escolhidas. Prefácio e notas de Antônio Sérgio e Hernani Cidade. Cartas (I). Lisboa: Livraria Sá da Costa Editora, 1951. Vol V.

VIEIRA, Pe. Antônio. "Direcções a respeito da forma que se deve ter no julgamento e liberdade no cativeiro dos índios do Maranhão" (Pará, 29 de setembro de 1655). In: Pe. Antônio Vieira. Obras Escolhidas. Prefácio e notas de Antônio Sérgio e Hernani Cidade. Vol.V - Obras Várias, 1951.

VIEIRA, "Sermão da Primeira Dominga de Quaresma". In Sermões. De acordo com a edição seiscentista, única autorizada. s/d. São Paulo: Editora das Américas, vol. XXI.

\section{Referências}

AGNOLIN Adone. Jesuítas e Selvagens. A negociação da Fé no encontro catequéticoritual americano-tupi (séc. XVI-XVII). São Paulo: Humanitas Editorial, 2007.

CHAMBOULEYRON, Rafael. "Em Torno das Missões Jesuíticas na Amazônia (século XVII)". Lusitania Sacra, $2^{\mathrm{a}}$ série, 15 (2003).

CHAMBOULEYRON, Rafael; ARENZ, Karl Heinz; NEVES NETO, Raimundo Moreira das. "Quem doutrine e ensine os filhos daqueles moradores: Jesuítas, Moradores e Colégios na Amazônia Colonial". Revista HISTEDBR On-line, v. 11, N. 43 e., p. 61-82, $2011 . \quad$ Disponível em: https://periodicos.sbu.unicamp.br/ojs/index.php/histedbr/article/view/8639954/7 517.

DIAS, Camila Loureiro. O Livro das Canoas - uma descrição. In: Anais do IV Encontro Internacional de História Colonial. Histórias e memórias indígenas. Rafael Chambouleyron \& Karl-Heinz Arenz (orgs.). Belém: Editora Açaí, volume 11, 2014.

DIAS, Camila Loureiro. "O comércio de escravos na Amazônia visto pelos Regimentos de entradas de tropas de resgate (séculos XVII e XVIII). Revista Territórios \& Fronteiras, Cuiabá, vol. 10, n. 1, jan.-jul., 2017.

EISENBERG; José. As Missões Jesuíticas e o Pensamento Político Moderno. Encontros culturais, aventuras teóricas. Belo Horizonte: Ed. UFMG/Humanitas, 2000.

HANSEN, João Adolfo. Correspondência de Antônio Vieira (1646-1694): o Decoro". Discurso. Revista do Departamento de Filosofia, FFLCH - USP. São Paulo, n 31, 2000, p.259-284.

HEMMING, John. Ouro Vermelho: A conquista dos índios brasileiros. São Paulo: Edusp, 2007.

HESPANHA, Antônio Manuel. Poder e Instituições no Antigo Regime. Lisboa, Ed. Gulbenkian, 1984.

HESPANHA, Antônio Manuel. Direito Comum e Direito Colonial. Panóptica, ano 1, n. 3 , nov. 2006, $\quad$ p. 97. Disponível em: http://www.metajus.com.br/textosestrangeiro/DireitoComumeDireitoColonial.pdf 
PAGDEN, Anthony. The Fall of Natural Man. The American Indian and the Origins of Comparative Ethnology. Londosn/New York/Melbourne, Cambridge University Press, 1982.

PÉCORA, Alcir. Teatro do Sacramento. A unidade teológico-retórico-política dos sermões de Antônio Vieira. Campinas: Editora Unicamp/ São Paulo: Edusp, 2ª ed., 2008.

PERRONE-MOISÉS, Beatriz, Índios Livres e Índios Escravos. O princípio da legislação indigenista do período colonial (século XVI a XVIII). In: História dos Índios no Brasil, Manuela Carneiro da Cunha (org), São Paulo: Companhia das Letras, São Paulo, 1992.

ZERON, Carlos Alberto de Moura. Linha de Fé. A Companhia de Jesus e a Escravidão no Processo de Formação da Sociedade Colonial (Brasil, Séculos XVI e XVII). São Paulo: Edusp, 2011.

ZERON, Carlos Alberto de Moura. A construção de uma ordem colonial nas margens americanas do Império Português: discussões sobre o "bem comum" na disputa de moradores e jesuítas pela administração dos índios (XVI-XVIII). Tese de livre-docência, São Paulo, FFLCH/USP, 2009.

\section{Notas de autoria}

Ludmila Gomides Freitas possui bacharelado em História (2001) e mestrado em História Cultural (2006) pela Universidade Estadual de Campinas. Doutorou-se em 2014 em História Social pela Universidade Federal de Uberlândia.Tem experiência na área de História, com ênfase em História do Brasil colonial e História Moderna, atuando principalmente nos seguintes temas: pensamento jurídico-teológico moderno, Padre Antônio Vieira, história indígena, política e legislação indigenista na América portuguesa, pedagogia jesuítica, história da escravidão. Entre 2014 - 2016 desenvolveu pesquisa de pós-doutorado no Instituto de Filosofia da Universidade Federal de Uberlândia, na área de Filosofia da Educação. Atualmente, é professora de História na Universidade Federal de São João del-Rei (UFSJ). E-mail: ludmilagomide394@gmail.com

\section{Como citar esse artigo de acordo com as normas da revista}

FREITAS, Ludmila Gomides. Política indigenista amazônica e os meandros da justiça nas cartas de Pe. Antônio Vieira. Sæculum - Revista de História, v. 24, n 41, p. 48-63, 2019.

\section{Contribuição de autoria}

Não se aplica.

\section{Consentimento de uso de imagem}

Não se aplica.

\section{Aprovação de comitê de ética em pesquisa}

Não se aplica.

\section{Licença de uso}

Este artigo está licenciado sob a Licença Creative Commons CC-BY. Com essa licença você pode compartilhar, adaptar, criar para qualquer fim, desde que atribua a autoria da obra.

\section{Histórico}

Recebido em 31/07/2019.

Aprovado em 16/09/2019. 